\title{
Attracting Foreign Direct Investment as an Economic Challenge for Ukraine in the Context of Globalization
}

\author{
Liudmyla Bezuhla* \\ Department Marketing \\ Dnipro State Agrarian and Economic \\ University \\ Dnipro, Ukraine \\ https://orcid.org/0000-0002-6520-4325
}

\author{
Iryna Kinash \\ Department of Management and \\ Administration \\ Ivano-Frankivsk National Technical \\ University oil and gas \\ Ivano-Frankivsk, Ukraine \\ https://orcid.org/0000-0002-5391-6560 \\ Olena Dovgal \\ Theory and Social Sciences Department \\ Mykolayiv National Agrarian \\ University \\ Mykolayiv, Ukraine \\ https://orcid.org/0000-0003-1683-5363
}

\author{
Uliana Andrusiv \\ Department of Theory of Economics \\ and management \\ Ivano-Frankivsk National Technical \\ University oil and gas \\ Ivano-Frankivsk, Ukraine \\ https://orcid.org/0000-0003-1793-0936
}

\begin{abstract}
The paper reflects topical issues related to the attraction of foreign direct investment. The various dynamics of direct foreign investments into and from the economy of Ukraine are investigated. Tendencies of changing indicators are established. The emphasis is placed on the fact that the volume of direct foreign investments per person remains low. Foreign direct investment is mostly from the EU. It is concluded that in recent years a lot of foreign investors have lost interest in the Ukrainian economy. The main reasons for this comprise the risks that we associate with economic and political instability; the corruption of power structures, the influence of negative factors, both social and geopolitical. Problems in the field of attraction of foreign investments, which require urgent solution, are revealed. Modeling of foreign direct investments into the Ukrainian economy has been conducted by the method of trend extrapolation and predicted values of the indicator. The directions, aimed at strengthening of investment attractiveness of Ukraine, are grounded.
\end{abstract}

Keywords - foreign investment, capital investment, rating, investment attractiveness, modeling.

\section{INTRODUCTION}

In modern conditions, the Ukrainian economy demonstrates weak economic dynamics of development, which is caused by low level of trust in the system of public administration, corruption, weak financial discipline and excessive debt burden. Ukraine lost its rightful place in the world economy. It is possible to improve the situation by attracting foreign direct investment, where the investment attractiveness of the state for foreign investors is one of the key indicators. We believe that Ukraine can attract investors, at the expense of its advantageous geographical location, a potentially large market, high qualification of the labor force and its relative cheapness; low exchange rate of the national currency; opportunities to repatriate profits.

Taking into account the European choice of Ukraine and the current state of development of the economy, our study aims at revealing trends in the volumes and structure of foreign direct investment in the Ukrainian economy, identifying problems and developing ways to increase the activity of investment processes.

\section{LITERATURE REVIEW}

The global economic crisis in 2008 witnessed a drop in indices of a number of economic indicators around the world. The global economic crisis in 2008 has witnessed a drop in indicators of a number of economic indicators around the world. Thus, the tendency towards decrease of direct foreign investments is shown in the work [1]. In order to restore the country's liquidity and solvency, various measures were taken that led to ambiguous results. Thus, in China during the crisis, the government initiated a package of economic incentives of four trillion yuan to invest in priority sectors of the country, such as construction and real estate, industry, healthcare, transport, education, restoration of the financial and credit system and reduction of tax pressure [2]. This allowed for restoring the country's economy at the expense of demand for mining and processing enterprises, which positively influenced their investment. It also positively influenced the consumer loans granting by banks, which indicates their solvency. Third, it positively influenced the development of the national economy, as it provided a motivation to scale the business at the expense of the country's development.

Regarding Europe, its regions have always been investment attractive having a high level of investment attraction. Scientists [3] explained such an attraction using the traditional neoliberal model in their work. Scientific researches [4] indicate that direct foreign investments into the economy of Slovakia contributed to increasing its competitiveness, created new jobs, mastered new technologies, provided access to know-how, and had a positive impact on managerial and entrepreneurial culture. 
The attractiveness of foreign direct investment has also been proved for countries that now have the status of candidate for the EU membership. Thus, [5] note that joining the European Union of Serbia will bring peace and improve the investment climate of the state, create conditions for the emergence of stable financial and macroeconomic environment. The authors emphasize that the most attractive sectors of the Serbian economy are the financial sector, as well as trade, tourism and telecommunications. According to them, foreign direct investment will contribute to sustainable economic development, which will affect the long-term presence of Serbia in the markets of the European Union.

As integration processes that involve the creation of conditions for the free movement of goods, services, capital, labor have become the priority trend in the politics of developed countries, this causes a steady increase in transnational flows and international transit of goods. In this regard, issues of freight transport greening [6], [7] are of particular importance. Scientists prove that transport greening positively influences the attraction of direct investments at the regional level. Influence of foreign investments on the investment climate of the state and its economic growth became the subject of research of Ukrainian scientists. Scientific developments [8] are devoted to the influence of foreign direct investment on Ukraine's export activity. In the research [9] the concept of "economic stability" is proposed, which is aims at increasing the investment climate in Ukraine and should ensure the development, security and investment attractiveness of the Ukrainian economy. Analysis of these sources suggests that in the context of globalization, the issue of attracting foreign direct investment to the state's economy, increasing its investment attractiveness, the possibilities of forecasting this process remain relevant and require further research, since it is to some extent an economic challenge for Ukraine.

The paper aims at studying and analyzing current trends of foreign investment in the state economy, outlining the problems of attracting investment, developing methods of solution.

\section{STUDY METHODS AND RESULTS}

Ukraine's economic development potential centers around resource provision. The most effective way to compensate for the lack of domestic resources is to attract foreign investment. Experts from the International Bank for Reconstruction and Development (IBRD) characterize the Ukrainian system of attracting foreign investment as overly complex and constantly changing. . Doing business is one of the major ratings published by the World Bank, and which investors pay attention to when choosing a state to invest their own funds. It takes into account the introduction of changes in legislation in order to improve the conditions for the implementation of entrepreneurial activities, including investment activities.

The study found that countries that rank in the top 10 of «Doing business» receive 50 times more foreign direct investment than those occupying the last positions. We will conduct a comparative analysis of Ukraine's rating positions in terms of: international trade, protection of minority investors, solving insolvency problems (Table 1). Ukraine ranked 115th in terms of international trade, yielding Poland (1 position), Belarus (30 position) and Moldova (34 position).

TABLE I. COMPARISON OF RATING POSITIONS OF EASE OF DOING BUSINESS IN UKRAINE WITH SOME COUNTRIES OF THE WORLD

\begin{tabular}{|c|c|c|c|c|c|c|c|c|c|c|c|c|}
\hline \multirow{2}{*}{$\begin{array}{c}\text { Index/ } \\
\text { (position) }\end{array}$} & \multicolumn{2}{|c|}{ Ukraine } & \multicolumn{2}{|c|}{ Poland } & \multicolumn{2}{|c|}{ Belarus } & \multicolumn{2}{|c|}{ Russia } & \multicolumn{2}{|c|}{ Moldova } & \multicolumn{2}{|c|}{ Georgia } \\
\hline & 2018 & 2017 & 2018 & 2017 & 2018 & 2017 & 2018 & 2017 & 2018 & 2017 & 2018 & 2017 \\
\hline $\begin{array}{l}\text { International } \\
\text { trade }\end{array}$ & 115 & 110 & 1 & 1 & 30 & 30 & 140 & 138 & 34 & 34 & 54 & 62 \\
\hline $\begin{array}{l}\text { Protection of } \\
\text { minority } \\
\text { investors }\end{array}$ & 70 & 101 & 42 & 40 & 42 & 62 & 53 & 51 & 42 & 40 & 7 & 22 \\
\hline $\begin{array}{c}\text { Solving } \\
\text { insolvency } \\
\text { problems }\end{array}$ & 150 & 148 & 27 & 33 & 69 & 95 & 51 & 49 & 60 & 58 & 106 & 101 \\
\hline
\end{tabular}

Research materials indicate that in 2015 the Ukrainian economy attracted foreign direct investment totaling 2961 million \$. In 2016 - 3284 million dollars which is $11 \%$ more compared to the corresponding period of 2015. In 2017, the volume of foreign direct investment in the Ukrainian economy amounted to 2.202 million \$ which is 1.082 million less compared to 2016. However, in 2018, there was a tendency to increase the volume of foreign direct investment [11]. Foreign direct investment is mostly from the EU countries. Thus, in 2017 alone Ukraine received 1244 million $\$$. In 2017, the main investor countries that invested in the Ukrainian economy were Cyprus (10008.6 million \$), the Netherlands (6292.9 million \$), Germany (1792.6 million \$), Russia (4598.4 million \$), Great Britain (2169 million \$) (Table 2).
The total share of these countries is more than $80 \%$ of all investments. Having investigated the structure of foreign direct investment in 2017 from the countries of the world into the Ukrainian economy, we found that 10685.6 million $\$$ were concentrated on the industrial enterprises $(41.1 \%$ of their total volume). Investments aimed at financial and insurance activity ranked second and made up $39.2 \%$. The results of the conducted research give grounds to assert that foreign investors prefer high profitable activities.

By examining the dynamics of foreign direct investment from the Ukraine's economy over the period under study, we see that their volume is practically 7 times smaller than the volume in the Ukrainian economy.

At the same time, the period of 2017-2018 was the most unfavorable for investments. 
TABLE II. FOREIGN DIRECT INVESTMENT (SHARE CAPITAL) FROM THE COUNTRIES OF THE WORLD IN THE ECONOMY OF UKRAINE

\begin{tabular}{|c|c|c|}
\hline Countries & $\begin{array}{c}\text { Volumes of direct investments as of 2017 } \\
(\text { million \$) }\end{array}$ & \% in total \\
\hline Cyprus & 10008.6 & 40.3 \\
\hline The Netherlands & 6292.9 & 25.3 \\
\hline Germany & 1792.6 & 7.2 \\
\hline Russian Federation & 4598.4 & 18.5 \\
\hline Great Britain & 2169 & 8.7 \\
\hline Total & 24861.5 & 100 \\
\hline
\end{tabular}

Source: composed by the authors based on [11]

Research materials have shown that every year own funds of enterprises and organizations remain the main source of financing for the development of the economy of Ukraine. Analyzing the sector's attractiveness of Ukraine, it can be argued that intensive investment processes are observed in highly profitable areas of economic activity.

At the same time, the period of 2017-2018 was the most unfavorable for investments. Research materials have shown that every year own funds of enterprises and organizations remain the main source of financing for the development of the economy of Ukraine. Analyzing the sector's attractiveness of Ukraine, it can be argued that intensive investment processes are observed in highly profitable areas of economic activity.

The investor at his own risk and discretion determines the expediency of placing funds in business of certain countries of the world. At the same time, investors take into account the investment climate of the state, in which they plan to invest. The index of investment attractiveness is an indicator. It should be noted that for the first half of 2018 the investment attractiveness index of Ukraine was 3.1 points (in 2017, it was 3.03 points) [12].

Research confirms that Ukraine has an investment attractiveness in attracting foreign investment in such areas: as tourism [13] a methodological approach to the economic evaluation of tourism development in Ukraine is proposed and its results confirming the possibility of investing in the tourism business are presented; agroindustrial complex [14], a methodology for assessing the competitiveness of enterprises of agroindustrial complex is presented construction industry [15] where the authors substantiate the methodological approach of attracting investment in the industry development of infrastructure and IT technology [16], [17], which proposes a model of transformation of economy and society from the point of view of investment attractiveness

In order to objectively assess the efficiency of investment processes in Ukraine, we observe the interconnections and interdependencies between investments and indicators that characterize the level of socio-economic development. The gross domestic product (GDP) is the general indicator reflecting the state of development of the country's economy. In the current situation, the economy of the country, requires a quick return on investment as never before.

We will forecast macroeconomic indicators with the help of economic-mathematical modeling. Extrapolation methods as well as economic and mathematical models (factor, econometric) are most widely used in forecasting GDP. The establishment of quantitative relations between volumes and dynamics of GDP and volumes and dynamics of investment resources in the country are the content and objectives of factor models of economic growth. With the help of the image of the dynamic series on the graph, the choice of the form of the equation is carried out. In this case, the determination coefficient is chosen as the main criterion for choosing the best curve for forecasting in most cases. The curve for which the determination coefficient is the largest is considered the best. At the same time, we emphasize that the trend extrapolation can be applied only if the phenomenon development is well described by the constructed equation and the conditions that determine the tendency of development in the past will not undergo significant changes in the future.

The Cobb-Douglas production function reflects the process of development of socio-economic systems objectively, without direct influence of the subjective factor. Therefore, it is expedient to apply this function to the mathematical description of the multiplicative relationship between GDP and investment.

The next step is to introduce the hypothesis needed to find out the form of regression relationship. Let's assume that the production regression is continuous and is twice differentiated. Further, we will assume that GDP of Ukraine $\mathrm{Y}$ depends on two factors: capital investments $\mathrm{X} 1$, and direct foreign investments $\mathrm{X} 2$.

$$
\mathrm{Y}=\mathrm{F}\left(\mathrm{X}_{1}, \mathrm{X}_{2}\right) \text {. }
$$

Hypothesis 1. If one of the factors X1, or X2 increases with the constant value of another, it leads to an increase in GDP and vice versa.

Changes in GDP due to a change in one of the factors $\mathrm{X} 1, \mathrm{X} 2$ is mathematically expressed as a partial derivative of this factor:

$$
\frac{\partial F}{\partial X_{1}}>0 ; \frac{\partial F}{\partial X_{2}}>0
$$

Hypothesis 2. Growth of GDP increases more slowly than the growth of costs of each of the investigated factors. In other words, the growth of one of the factors per unit causes an increase in GDP less than one.

Hypothesis 3. The production function $F(X 1, X 2)$ is a homogeneous function relative to the factors $\mathrm{X} 1, \mathrm{X} 2$, with the homogeneity index a. As a result, simultaneously increasing the values of factors $\lambda$ times (any constant number), we get an increase in GDP $\lambda^{\mathrm{a}}$ times:

$$
\mathrm{F}\left(\lambda \mathrm{X}_{1}, \lambda \mathrm{X}_{2}\right)=\lambda^{\mathrm{a}} \mathrm{F}\left(\mathrm{X}_{1}, \mathrm{X}_{2},\right) \text {. }
$$


Hypothesis 4. The elasticity of investments is a constant positive value on the line of constant GDP.

The equation of the production regression of CobbDouglas obtained on the basis of these hypotheses will have the following form:

$$
\mathrm{Y}=\mathrm{a}_{0} \mathrm{X}_{1}^{\mathrm{a} 1} \mathrm{X}_{2}^{\mathrm{a} 2}
$$

Thus, to solve the problem of forecasting GDP growth, we calculate the parameters of the Cobb-Douglas production function. Geometrically, the production regression can be illustrated as a surface in a three-dimensional space with coordinates $\mathrm{X} 1, \mathrm{X} 2, \mathrm{Y}$.

In order to evaluate the parameters of the regression line, you need to logarithm the equation and replace the values:

$$
\begin{gathered}
\ln \mathrm{Y}=\ln \mathrm{a}_{0}+\mathrm{a}_{1} \ln \mathrm{X}_{1}+\mathrm{a}_{2} \ln \mathrm{X}_{2}, \\
\mathrm{a}_{01}=\ln \mathrm{a}_{0}, \mathrm{Y}_{1}=\ln \mathrm{Y}, \mathrm{Z}_{1}=\ln \mathrm{X}_{1}, \mathrm{Z}_{2}=\ln \mathrm{X}_{2} .
\end{gathered}
$$

These transformations allowed us to get a linear model

$$
\mathrm{Y}_{1}=\mathrm{a}_{01}+\mathrm{a}_{1} \mathrm{Z}_{1}+\mathrm{a}_{2} \mathrm{Z}_{2} \text {. }
$$

To calculate the coefficients a01, a1, a 2 it is convenient to use spreadsheets.

The required calculations for estimating the parameters

\begin{tabular}{|c|c|c|c|c|c|c|c|c|c|}
\hline Year & $Y$ & $X 1$ & $X 2$ & $Y 1=\ln (Y)$ & $Z_{1}=\ln (X 1)$ & $Z_{2}=\ln (X 2)$ & $Y_{I} r$ & Y1min & Y1max \\
\hline 2011 & 133981.3 & 23398.6 & 39582.1 & 13.89 & 12.15 & 12.68 & 13.96 & 13.76 & 14.16 \\
\hline 2012 & 162759.9 & 32491.5 & 44591.4 & 14.08 & 12.47 & 12.78 & 14.08 & 13.88 & 14.28 \\
\hline 2013 & 171683.4 & 32083.7 & 48924.3 & 14.16 & 12.48 & 12.90 & 14.14 & 13.94 & 14.33 \\
\hline 2014 & 95719.1 & 1643.9 & 29078.1 & 14.19 & 12.43 & 13.00 & 14.17 & 13.97 & 14.37 \\
\hline 2015 & 66106,7 & 9258.2 & 15485.5 & 14.26 & 12.30 & 12.81 & 14.06 & 13.86 & 14.25 \\
\hline 2016 & 72774.2 & 10044,1 & 38265.2 & 14.50 & 12.52 & 13.86 & 14.57 & 14.37 & 14.77 \\
\hline 2017 & 87746 & 13225.9 & 37697.4 & 14.68 & 12.79 & 13.84 & 14.62 & 14.42 & 14.82 \\
\hline 2018 & 86271.2 & 16220.6 & 39734.6 & 14.68 & 13.01 & 13.91 & 14.70 & 14.50 & 14.90 \\
\hline Total & 810935.10 & 153161.60 & 293358.60 & 219.21 & 191.73 & 194.82 & 219.21 & & \\
\hline
\end{tabular}
of the regression line and the application of the Excel Analysis Package are given in Table 3.

TABLE III. CALCULATIONS FOR ESTIMATING THE PARAMETERS OF THE REGRESSION LINE (MILLION \$)

After conducting all calculations in Excel, we obtain:

$\mathrm{a}_{1}=0.209, \mathrm{a}_{2}=0,=.45398, \mathrm{a}_{0}=288.3338$.

The production function has the form

$$
\mathrm{Y}=288.3338 \mathrm{X}_{1}{ }^{0.209} \mathrm{X}_{2}{ }^{0.45398}
$$

The received, actual and projected results as well as the confidence interval are given in Table 4.

For multi-factor regression, the partial elasticity coefficient shows how much the indicator will change if one of the factors changes by one percent at constant values of other factors.

If the regression line has the form $\mathrm{Y}=\mathrm{f}[\mathrm{X} 1, \mathrm{X} 2, .$. $\mathrm{Xm}$ ), then the partial coefficient of elasticity for the factor

\begin{tabular}{|c|c|c|c|c|c|c|}
\hline Year & $Y$ & $X 1$ & $x 2$ & $Y r=\exp \left(Y_{I} r\right)$ & Ymin & $\operatorname{Ymax}$ \\
\hline 2011 & 133981.3 & 23398.6 & 39582.1 & 143229.6 & 117351.7 & 174813.9 \\
\hline 2012 & 162759.9 & 32491.5 & 44591.4 & 162481.4 & 133125.2 & 198311.1 \\
\hline 2013 & 171683.4 & 32083.7 & 48924.3 & 167457.3 & 137199.1 & 204379.7 \\
\hline 2014 & 95719.1 & 1643.9 & 29078.1 & 93447.2 & 76563.7 & 114053.7 \\
\hline 2015 & 66106,7 & 9258.2 & 15485.5 & 53616.3 & 43929.2 & 65439.5 \\
\hline 2016 & 72774.2 & 10044,1 & 38265.2 & 78386.4 & 64223.9 & 95671.8 \\
\hline 2017 & 87746 & 13225.9 & 37697.4 & 82528.6 & 67617.8 & 100727.5 \\
\hline 2018 & 86271.2 & 16220.6 & 39734.6 & 87681.6 & 71839.8 & 107016.7 \\
\hline 2019 ( forecast) & & 19159.2 & 53914.4 & 106430.4 & 106228,7 & 106728,4 \\
\hline 2020 (forecast) & & 21249.6 & 59256.6 & 110443,9 & 110442,2 & 110458,8 \\
\hline 2021(forecast) & & 23719.9 & 65035.3 & 119936.1 & 119928.7 & 119938.4 \\
\hline
\end{tabular}
$\mathrm{Xi}$ is calculated by the formula:

$$
k_{x_{i}}=\frac{\partial f}{\partial X_{i}} \cdot \frac{X_{i}}{f},(\mathrm{i}=1, \mathrm{~m})
$$

TABLE IV. ACTUAL, CALCULATED AND PROJECTED VALUE AND CONFIDENCE INTERVAL (MILLION \$)

Let's find partial elasticity coefficients for the CobbDouglas production regression $\mathrm{Y}=\mathrm{a}_{0} \mathrm{X}_{1}{ }^{\mathrm{a}} \mathrm{X}_{2}{ }^{\mathrm{a}}$ :

$$
k_{x_{1}}=\frac{\partial f}{\partial X_{i}} \cdot \frac{X_{i}}{f}=\frac{\partial\left(a_{0} X_{1}^{a_{1}} X_{2}^{a_{2}}\right)}{\partial X_{1}} \cdot \frac{X_{1}}{a_{0} X_{1}^{a_{1}} X_{2}^{a_{2}}}=\frac{a_{0} a_{1} X_{1}^{a_{1}-1} X_{2}^{a_{2}} X_{1}}{a_{0} X_{1}^{a_{1}} X_{2}^{a_{2}}}=a_{1}
$$


Thus, the parameter a1 is a partial coefficient of elasticity of factor X1 of the Cobb-Douglas production regression. It shows that GDP changes by 0.210 percent, if the factor of capital investment changes by $1 \%$ at constant values of factor of foreign direct investment. Since the coefficient of elasticity is positive, the increase (decrease) of the factor causes, respectively, an increase (decrease) of the indicator.

The partial coefficient of elasticity for the second factor (found similarly) is equal to the second parameter $\mathrm{kx} 2=\mathrm{a} 2$ and, accordingly, shows that the change in the factor of direct foreign investment by $1 \%$ causes the change of GDP index by 0.4525 percent at constant values of the factor of capital investments.

The homogeneity of the production regression from an economic point of view is evidenced by the hypothesis 3 . Increasing the volume of factors into any constant number $\lambda$ will give an opportunity to trace the reaction of GDP change to such changes of factors.

Let's assume that at a certain point in time, the factors and the indicator had values $\mathrm{x}_{10}, \mathrm{x}_{20}, \mathrm{y}_{0}$, i.e. $\mathrm{Y}_{0}=\mathrm{a}_{0} \mathrm{X}_{10}{ }^{\mathrm{a} 1} \mathrm{X}_{20}{ }^{\mathrm{a} 2}$. After increasing the factors in $\lambda$ times we'll get:

$$
\begin{gathered}
\mathrm{Y}=\mathrm{a}_{0} \mathrm{X}_{1}{ }^{\mathrm{a} 1} \mathrm{X}_{2}{ }^{\mathrm{a} 2}=\mathrm{a}_{0}\left(\lambda \mathrm{X}_{10}\right)^{\mathrm{a} 1}\left(\lambda \mathrm{X}_{20}\right)^{\mathrm{a} 2}=\lambda^{\mathrm{a} 1+\mathrm{a} 2} \\
\mathrm{a}_{0} \mathrm{X}_{10}{ }^{\mathrm{a} 1} \mathrm{X}_{20}{ }^{\mathrm{a} 2}=\lambda^{\mathrm{a} 1+\mathrm{a} 2} \mathrm{Y}_{0}
\end{gathered}
$$

The homogeneity index, in this case, is equal to the sum of partial elasticity coefficients:

$$
\mathrm{a}=\mathrm{a}_{1}+\mathrm{a}_{2}
$$

This homogeneity index is called the total coefficient of elasticity. Given that the value of the overall coefficient of elasticity is less than one, then the increase in investment in $\lambda$ (the constant number is more than one) times will cause GDP to increase by a number of less than $\lambda$, i.e. в $\lambda^{\mathrm{a} 1+\mathrm{a} 2}$, де $\mathrm{a}_{1}+\mathrm{a}_{2}<1$.

Verification is the final stage in the development of the forecast. It is a procedure for assessing the reliability, accuracy or reasonableness of the forecast.

In order to make an estimation of the found econometric model for adequacy, it is necessary to compare the calculated value of the F-test with the table.

For a given reliable probability $\mathrm{p}=0.95(\mathrm{a}=1-\mathrm{p}=0.05$ level of significance) and the number of degrees of freedom $\mathrm{k} 1=\mathrm{m}=2, \mathrm{k} 2=\mathrm{n}-\mathrm{m}-1=13$ we find the table value $\mathrm{F}(\mathrm{a}$, $\mathrm{k} 1, \mathrm{k} 2)$ :

$$
\text { Ftab. }(0.05 ; 2 ; 13)=3.81 \text {. }
$$

The obtained calculated value of Fcalc $=504.415$ is compared with the table.

With a probability of 0.95 we can assume that the considered econometric model is adequate to the initial data, since Fcalc> Ftab

Due to the factorial analysis of the dynamics of GDP, capital investment, and foreign direct investment the following results were obtained:

1) the elasticity of GDP by capital investment for the period of 2011-2018 amounted to 0.210. This means that with an increase in the volume of capital investments by $1 \%$ (for other unchanged factors) GDP could increase by $0.210 \%$. Accordingly, with a decrease in investment by $1 \%$ (for other unchanged factors) there was a reduction of GDP by $0.210 \%$;

2) the elasticity of GDP for foreign direct investment in the period of 2011-2018 is 0.4525 . This means that with an increase in foreign direct investment by $1 \%$ (for other unchanged factors), GDP could increase by $0.4525 \%$. Accordingly, with a decrease in foreign direct investment by $1 \%$ (for other unchanged factors) there was a reduction of GDP by $0.4525 \%$;

3) simultaneous reduction of both factors by $1 \%$ caused a fall in GDP by $0.663 \%$;

4) the estimated value of F-test with a probability of 0.95 far exceeds the table one and is an indication that the considered econometric model of the Cobb-Douglas production function is adequate to the initial data;

5) projected GDP values obtained while applying the Cobb-Douglas production function, which takes into account the impact of investment resources in 2019 106430.4 million \$, in 2020 - 110443,9 million \$, in 2021 119936.1 million \$.

Let's outline the problems in attracting foreign investments, which, need to be resolved: to put in place legislation that would protect the rights of private investors; improve tax regulation; create an infrastructure for foreign entrepreneurship; develop a financial market. The use of public-private partnerships can be an effective tool for stimulating investment processes.

\section{CONCLUSIONS}

In the context of globalization, investments play an important role in shaping Ukraine's development potential and ensuring its economic growth.

The tendency of attraction of foreign direct investments into the state economy has been analyzed. It is concluded that in recent years, a large number of foreign investors have lost interest in the Ukrainian economy. It is determined that by 2013 the volume of investments into the economy of the country grew from year to year. However, since 2014, the volume of investment has been decreasing, and in 2018 it was $13 \%$ lower than in 2014. The volume of foreign direct investments in Ukraine per person during the studied period remains as low as 1000 USD. Foreign direct investment comes mostly from the EU. Investigating the structure of foreign direct investment into the economy of Ukraine, we found that $41.1 \%$ of the total investment is concentrated in the enterprises of the industry. Investments in financial and insurance activities rank second (39.2\%).

The problems and prospects of attracting foreign investments have been highlighted. The following issues need to be addressed urgently: to introduce legislation that protects the rights of private investors; improve tax regulation; create infrastructure for foreign entrepreneurship; to develop the financial market. It is established that the general indicator reflecting the state of economic development of the country is the gross domestic product. Forecasting of the studied macroeconomic 
indicators by means of economic and mathematical modeling is carried out.

Improvement of the the investment climate in Ukraine can be achieved at the expense of: improving state regulation; creation of the necessary conditions for attracting foreign investments; protection of property rights of foreign investors; a rational combination of the interests of the state, foreign investors and domestic producers; a permanent dialogue with the government on problematic issues of attracting foreign investments into the state's economy. Using of public-private partnerships can be an effective tool for stimulating investment processes.

\section{REFERENCES}

[1] A. Dixit, "International trade, foreign direct investment, and security", Annual Review of Economics, Vol. 3, No. 1, pp. 191-213, 2011

[2] E. Aisbett, L. Karp \& C. Ausland, "Police powers, regulatory takings and the efficient compensation of domestic and foreign investors", Economic Record, Vol. 86, No.274, pp. 367-383, 2010. doi:http://dx.doi.org/10.1111/j.1475-4932.2009.00616.x

[3] E. Robinson, "Reassessing the interaction between investment and tenure uncertainty", Environment and Development Economics, Vol.10, No. 2, pp. 143-157, 2005.

[4] M. Fabus, "Impact of foreign direct investment on unemployment development in selected regions of Slovak Republic", Economic Annals-XXI, Vol. 155, No. 11-12, pp. 63-66, 2015

[5] B. Dudić, Z. Dudić, J. Smoleň, \& , V. Mirković, "Support for foreign direct investment inflows in Serbia", Economic Annals-XXI, Vol. 169, No.1-2, pp. 4-11, 2018.

[6] R. Sappideen, Ling Ling, "Dispute resolution in investment treaties: balancing the rights of investors and host states", Journal of World Trade, Vol.49, No. 1, pp. 85-116, 2015.

[7] S.Franck, L. Wylie, "Predicting outcomes in investment treaty arbitration”, Duke Law Journal, Vol. 65, pp. 459-525, 2015.
[8] S. Moroz, K. Pirmatov, E. Horská, L’Nagyová, Z. Poláková, “The effect of selected economic indicators on export of goods of regions of Ukraine", Montenegrin Journal of Economics, Vol. 13, No. 2, pp. 141-150, 2017. doi: 10.14254/18005845/2017.13-2.9

[9] S. Kozlovskyi, I. Khadzhynov, I. Vlasenko, L. Marynchak, "Managing the sustainability of economic system as the basis of investment development in Ukraine", Investment Management and Financial Innovations, Vol.14, No. 4, pp. 50-59, 2017.

[10] Doing business rating, 2018. [Online]. Available: http:// doingbusiness.org. Accessed on: March 19, 2019.

[11] State statistics service of Ukraine, 2018. [Online]. Available: http://www.ukrstat.gov.ua. Accessed on: April 21, 2018.

[12] Association Agreement between Ukraine and the European Union and its member states, 2014. [Online]. Available: https://eu-ua.org/uhodapro-asotsiatsiiu. Accessed on: June 27, 2014.

[13] I. Kinash, L. Arkhypova, A. Polyanska, O. Dzoba, U. Andrusiv and Iu. Iuras, "Economic evaluation of tourism infrastructure development in Ukraine", in IOP Conference Series: Materials Science and Engineering, Banja Luke, 2018, Vol. 477, No. 1. Available: $\quad$ https://iopscience.iop.org/article/10.1088/1757899X/477/1/012020

[14] O. Dovgal, M. Kravchenko, N. Demchuk, O. Odnoshevnaya, O. Novikov, U. Andrusiv, I. Lesik, I. Popadynets, "Methods of competitiveness assessment of agricultural enterprise in Eastern Europe", Regional Science Inquiry, Vol. 9, No. 2, pp. 231-242, 2017.

[15] U. Andrusiv, O. Galtsova, "Evaluation of innovation activity of construction enterprises", Scientific bulletin of Polissia, Vol. 3 (11), P. 1. pp. 204 - 215, 2017. doi: 10.25140/2410-9576-2017-1-3(11)204-215.

[16] V. Boronos, I. Plikus, \& V. Aleksandrov, "Digital transformation of Ukraine: challenges of theory and practice in the implementation of digital quality of life", Economic Annals-XXI, Vol. 172, No. 7-8, pp. 38-43, 2018. doi: https://doi.org/10.21003/ea.V172-07.

[17] N.Korzh, T. Mostenska, and Y. Bilan, «Resource-based view in managing financial component of corporate capital» Polish Journal of Management Studies, Vol.16(2), pp. 133-146, 2017. doi: 10.17512/pjms.2017.16.2.12. 